\title{
Percutaneous ruminostomy guided by rumenoscopy: study in an experimental model in bovine fetus
}

\author{
Gabriela Melo Alves dos Santos ${ }^{1}$, Luisa Pucci Bueno Borges ${ }^{1}$, Hanna Lyce Magno de Morais', \\ Barbara da Conceição Guilherme ', Rodrigo dos Santos Albuquerque ', Kayan Cunha Rossy', \\ Heytor Jales Gurgel', Camila do Espirito Santo Fernandes', João Pedro Monteiro Barroso', \\ Priscila do Santos Ribas ${ }^{1}$, Francisco Décio de Oliveira Monteiro ${ }^{* *}$, Chayanne Silva Ferreira ${ }^{2}$ and \\ Pedro Paulo Maia Teixeira ${ }^{1}$
}

\begin{abstract}
Background: Endosurgery is a surgical subspecialty that has been widely used in production animals, because it enables good visualization of abdominal organs and the diagnosis and treatment of several conditions in a minimally invasive manner, while preserving the animal's well-being and causing a lower impact on animal production. Rumenostomy is one of the most common surgical procedures in ruminants. This procedure is used to allow access to the rumen for various purposes, especially nutritional and therapeutic studies, and it can be performed either in a conventional way or in a minimally invasive video-assisted manner. Another possibility of access to ruminants is through the rumenoscopy technique. The objective of this study is to describe a minimally invasive technique for rumenostomy using an endoscope, working on a bovine fetal corpse as an experimental model.
\end{abstract}

Results: The execution of the endoscopy-guided rumenostomy technique was simple and did not present major difficulties. The endoscope, its lighting and air pump, and the decubitus used provided a good anatomical visualization of the rumen, and it was possible to evaluate several regions of the organ. The mean duration of the procedure was $11.15 \mathrm{~min}$.

Conclusions: The endoscopic rumenostomy technique using anatomical pieces of calves was shown to be feasible. It was performed in a simple and efficient way, particularly regarding the premise of preserving the animal's wellbeing, due to its minimally invasive nature.

Keywords: Ruminants, Rumen surgery, Rumen cannulation, Endoscopy

*Correspondence: deciomonteiro@ifto.edu.br

${ }^{1}$ Veterinary Hospital, Veterinary Institute, Federal University of Pará (HV/ IMV/UFPA) Castanhal Campus II, Br 316, Km 62, Castanhal, PA 68743-970, Brazil

Full list of author information is available at the end of the article

\begin{abstract}
Background
Endosurgery is a surgical subspecialty that has been widely used in production animals. It has shown increasingly promising results [26] and in many cases has become the surgical technique of choice, since it allows good visualization of abdominal organs [4] and the diagnosis and treatment of several conditions in a minimally invasive manner, while preserving the animal's well-being and causing a lower impact on animal production [34].
\end{abstract}

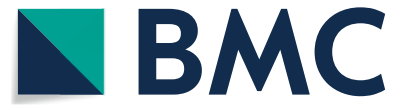

(c) The Author(s) 2022. Open Access This article is licensed under a Creative Commons Attribution 4.0 International License, which permits use, sharing, adaptation, distribution and reproduction in any medium or format, as long as you give appropriate credit to the original author(s) and the source, provide a link to the Creative Commons licence, and indicate if changes were made. The images or other third party material in this article are included in the article's Creative Commons licence, unless indicated otherwise in a credit line to the material. If material is not included in the article's Creative Commons licence and your intended use is not permitted by statutory regulation or exceeds the permitted use, you will need to obtain permission directly from the copyright holder. To view a copy of this licence, visit http://creativecommons.org/licenses/by/4.0/. The Creative Commons Public Domain Dedication waiver (http://creativeco $\mathrm{mmons}$.org/publicdomain/zero/1.0/) applies to the data made available in this article, unless otherwise stated in a credit line to the data. 
The advantages of endosurgery include less tissue injury, lower risk of infections and post-operative pain due to a smaller surgical incision, less exposure and manipulation of the viscera, shorter surgical time, and faster recovery for the animal. These factors should be taken into consideration when deciding the surgical technique to be used $[9,36]$.

Numerous surgical procedures can be performed through the endosurgical approach, including laparoscopy, which allows access, visualization, and manipulation of the abdominal cavity and its organs. Laparoscopy can be performed for various purposes, such as abomasopexy [1], kidney biopsy [7], liver biopsy [10], cystotomy [15] ovariectomy $[2,3,34]$.

Rumenostomy is one of the most common surgical procedures in ruminants. It is used to open an access to the rumen, either temporarily or permanently, and has several purposes, particularly animal nutrition studies to assess digestibility and rumen metabolism and to evaluate animals that will serve as donors of ruminal inoculum $[29,32,37]$, in addition to therapeutic purposes, such as cases of relapsing tympanism due to vagal indigestion [30], calves with tympanism due to esophageal groove dysfunction [22], and enteral nutrition [5].

In its traditional forms, rumenostomy has variations regarding the material used. It can use either a rigid cannula [12, 24] or a flexible one [34]. Regarding its execution, it is possible to perform it in either one or two surgical stages [27, 35]. In 2018, Santos et al. described a minimally invasive technique of video-assisted rumenostomy in sheep. In ruminants, another possibility is rumenoscopy, which through the use of an endoscope makes it possible to visualize the structures of the rumen $[14,25]$.

The use of animals in the study of techniques and treatments, in both veterinary and human medicine, is still questioned and much discussed. The " $3 \mathrm{R}$ principle" (reduction, refinement, replacement), established by William Russell and Rex Burch in 1959, is most widely used by researchers, because it emphasizes the importance of developing studies that allow a reduction in the number of animals used without impacting the reliability of the results; the replacement of the use of animals by other research models, such as the use of "organs-on-a-chip," three-dimensional and computerized tissue models, and the model used in the present study; and the refinement of techniques that have less impact on animal health $[6$, $18,20]$.

In this same sense, the choice of minimally invasive procedures becomes increasingly advantageous and necessary, since it allows results and advances to be obtained while considering the ethics in animal experimentation and the animals' well-being $[28,34]$. Other studies also seek alternative techniques for rumen cannulation with esophageal or nasoesophageal probes, particularly in cases where it is necessary to repeat the procedure several times in the same animal [32].

Therefore, the aim of this study is to describe and standardize a minimally invasive rumenostomy technique by ororuminal endoscopy and percutaneous cannulation, working on an experimental model in bovine fetus corpses, which had been previously slaughtered by accident and would be discarded in local slaughterhouses.

\section{Results}

The endoscopy-guided rumenostomy technique shown to be feasible and presented no difficulties or complications.

The endoscope's air pump was sufficient to inflate the organ and allow its internal visualization. The endoscope provided a good anatomical visualization of the rumen, from its entrance from the esophagus to its internal structures, and it was possible to evaluate the dorsal and ventral sacs of the rumen, the caudodorsal and caudoventral blind sacs, the dorsal and ventral coronary pillars, and the caudal pillar (Fig. 1G).

The decubitus used, the transillumination from the endoscope, and the palpation on the flank showed to be adequate for locating and positioning the probe in the left paralumbar fossa. The catheter used for the passage of the guide probe and the endoscopic probe showed to be efficient for the objectives of this study.

The mean duration of the procedure, from the passage of the endoscope, inflation, and passage of the guide and probe to the incision and fixation of the probe, was $11.15 \pm 0.7 \mathrm{~min}$.

\section{Discussion}

The technique established in this study proved to be efficient in terms of the simplicity of its approach. A technique similar to the presently described one is percutaneous endoscopic gastrostomy, performed in humans and described by Gauderer et al. in 1980, which has indications in cases of patients unable to eat normally for reasons such as neuropathies, congenital diseases, neoplasms, traumas, etc. The main advantages of both techniques are the possibility of gastrostomy without the need for laparotomy, avoiding further injuries to patients; less postoperative pain; and shorter surgical and anesthetic time.

Some minimally invasive techniques performed in the gastrointestinal tract of ruminants have been described, including laparoscopic abomasopexy, used to treat abomasum displacement, and laparoscopic abomasal cannulation $[1,19,38]$.

Rumenoscopy is the visualization of the ruminal structures with an endoscope. It allows the cannulation of the 


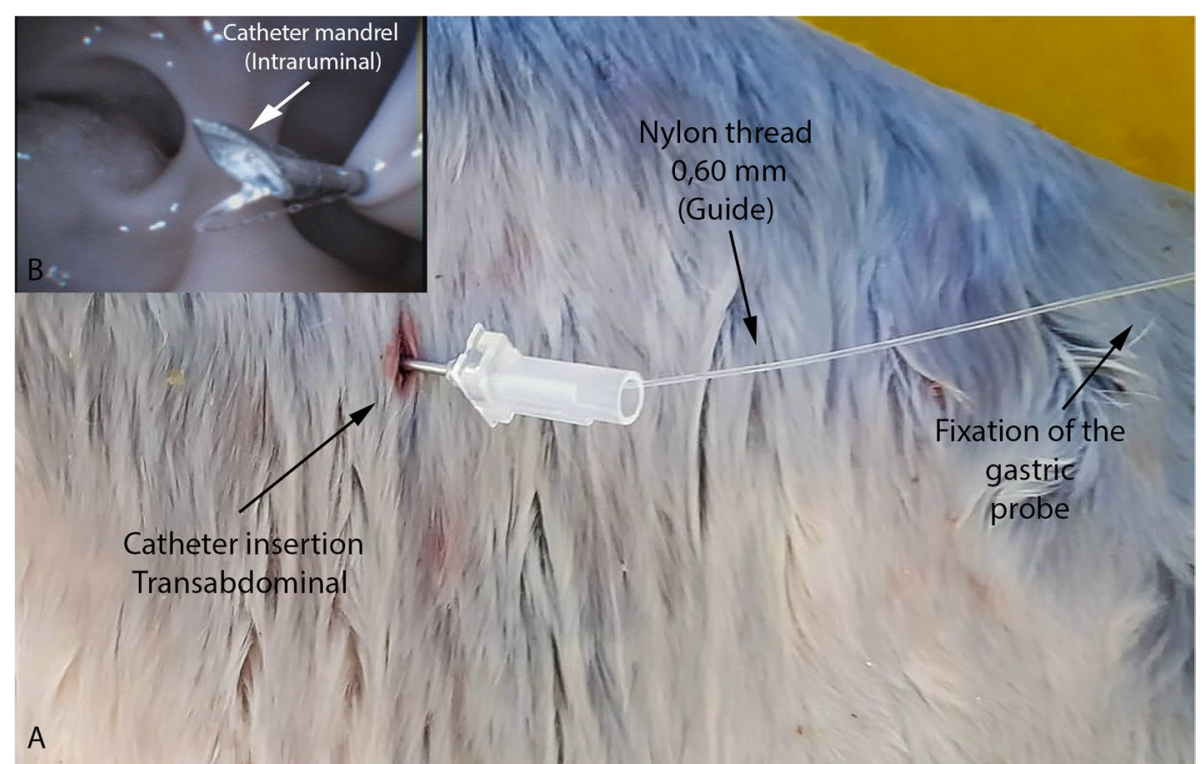

Fig. 1 Catheter insertion transabdominal. A External view of the catheter and guidewire; B Internal view of the catheter needle and the introduction of the tube guidewire. Catheter needle

rumen, as described in this study. It is believed that percutaneous rumenostomy by rumenoscopy can be performed without the use of general anesthesia, only with the use of sedation for chemical containment, plus simple locoregional anesthesia, meeting this procedure's goals of less invasiveness and lower anesthetic risk [13, 14, 25].

The mean duration obtained for the rumenoscopyguided rumenostomy procedure was $11.15 \pm 0.7 \mathrm{~min}$. Minimally invasive techniques tend to have less surgical time than conventional techniques. In the newly developed video-assisted rumenostomy technique, the time obtained was $13 \pm 6.2 \mathrm{~min}$ [31], while in conventional techniques, the surgical time varies from 15 to $25 \mathrm{~min}$ [33] when performed in a surgical stage. In humans, percutaneous endoscopic gastrostomy was performed in $8 \pm 3 \mathrm{~min}$, while the open surgical gastrostomy technique had a mean duration of $35 \pm 1.3 \mathrm{~min}$ [11].

It is important to highlight that the time in endosurgical techniques depends on the training and experience of the surgeon and the surgical team, as well as on the proper use of the devices to avoid complications and to ensure a good execution of the procedures $[9,21]$.

The decubitus used in this rumenoscopy technique was efficient, as well as that used in the laparoscopy rumenostomy procedure. In this same procedure, the 36-h fast, combined with the decubitus, allowed a good visualization and manipulation of the rumen, in addition to avoiding regurgitation and inhalation of rumen contents. However, although the percutaneous endoscopic rumenostomy has not yet been tested in live animals, it is believed that the rumenoscopy technique can be performed in standing animals $[13,14,31]$.

The visualization of the structures and the possibility of performing the technique in neonate animals using the present study's model have been confirmed. Further studies are also necessary to verify this technique's feasibility in adult and larger animals, in which the presence of rumen content, ruminal motility, and larger organ size and length can be complicating factors.

The proposed model has some important points and limitations that require attention when it is eventually tested in living animals. The age of the corpses used, in which the rumen is not yet the main gastric compartment, is one of these factors. The size of the piece and the fact that it is a corpse imply that performing this technique and visualizing the ruminal structures are easier, despite the absence of the peristaltic movements, rumen content, and resistance of the animal to the endoscope.

Franz and Baumgartner, in 2002, used a 100-cm long endoscope for calves up to 7 months of age, and a $150-\mathrm{cm}$ endoscope for animals between 7 months and 6 years of age. The endoscope used in the present study was $100 \mathrm{~cm}$ long, which can be a limiting factor for performing the technique in older and larger animals, as it may make it impossible to reach the desired site for cannulation.

Another factor that will need to be evaluated when this technique is tested in live animals is the need for rumenopexy, especially in older and larger animals, due to the weight of the rumen. In 2020, Griffin et al. described a new gastrostomy technique in canine models and 


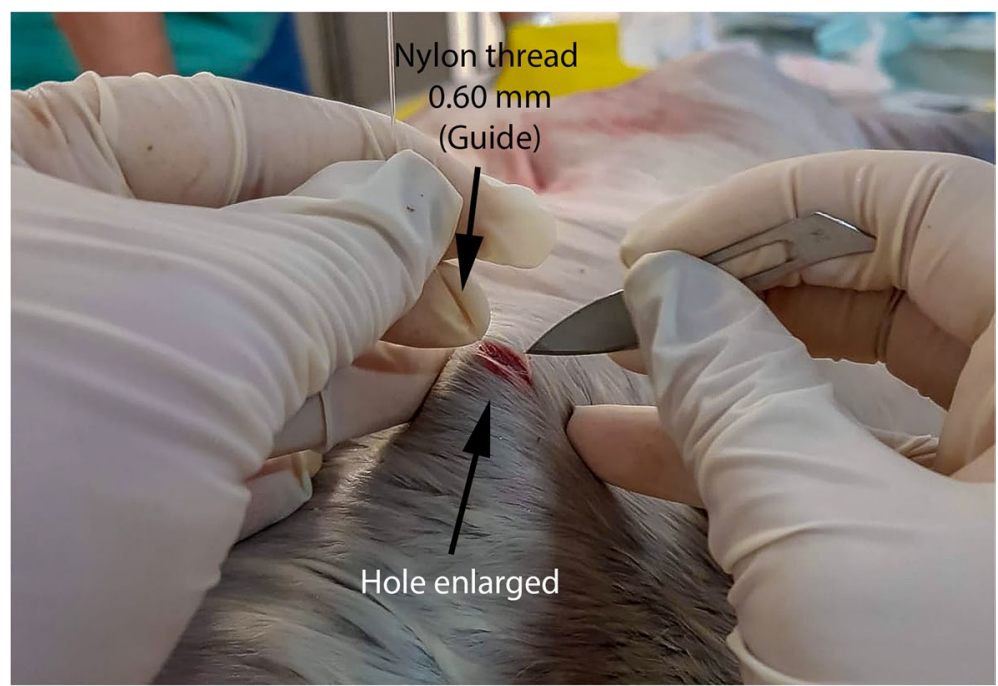

Fig. 2 Puncture-incision made to allow the tube exit. Tube's guidewire

highlighted the importance of gastropexy to help prevent complications such as leakage of the stomach contents, especially in dogs weighing more than $25 \mathrm{~kg}$.

As already mentioned earlier, studies involving the cannulation of gastric chambers in ruminants are extremely necessary for animal experimentation, though the clinical need is also a reality [30, 38]. Some specific cases, such as studies on the mitigation of methane produced by ruminants, are extremely important scientific issues today $[8,23]$.

Thus, the proposed models are the most compatible, because conventional cannulas would interfere with the gas exchange of the rumen with the ambient air, due to cannula displacement, a relatively frequent event [35], as well as at the moment of opening the cannula. These problems were the factors that encouraged our team to develop an in vivo model of minimally invasive rumenostomy in sheep [31], since rumen puncture for many days would bring injury, cannula opening, and ambient air intake, and an oral probe would contaminate the sample with saliva. However, the model can also be executed by new proposed techniques, in simpler and more practical ways.

\section{Conclusion}

The percutaneous endoscopic rumenostomy technique was found to be feasible and efficient when performed in experimental models.

\section{Methods}

As the study corresponds to a new experimental technique, all procedures were performed on cadavers from a locals laughterhouse in accordance with inspection requirements. Tus, the procedures did not cause pain or sufering in animals, as they were performed on bovine fetuses from the slaughtered of pregnant cows. Therefore, is in accordance with Law 11.794 of October 8, 2008, Decree 6899 of July 15, 2009, as well as with the rules issued by the CONCEA, and was approved by the CEUA/ UFPA in the meeting of 04/30/2020.

Five anatomical pieces $(n=5)$ were used, corpses of bovine fetuses that were estimated to be between 7 and 9 months of fetal age, resulting from the disposal of a local meat processing company, in which the technique of percutaneous rumenostomy performed by ororuminal endoscopy was used.

The procedure can be better visualized if divided into two stages. The first stage explains the rumenoscopy procedure and the second explains the rumenostomy.

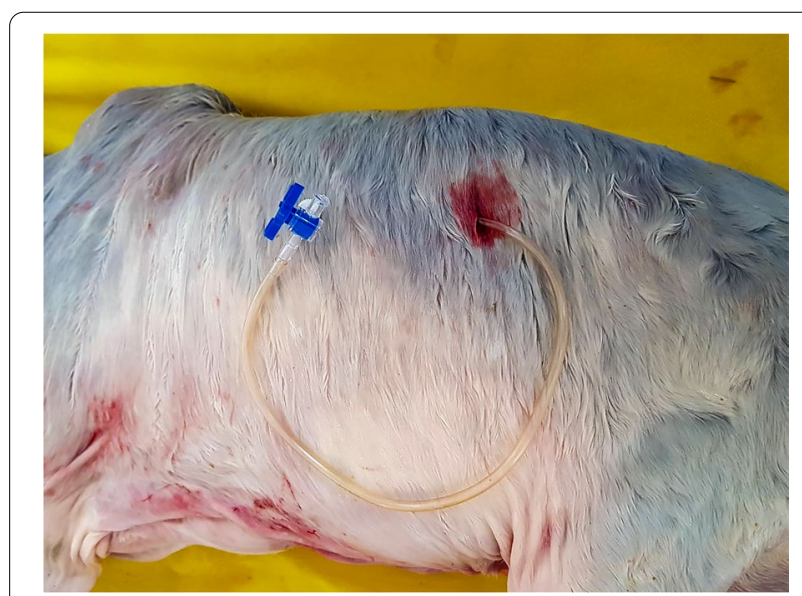

Fig. 3 External view of the final positioning of the probe with the three-way stop-cock coupling. Tube used in this tecnique description 


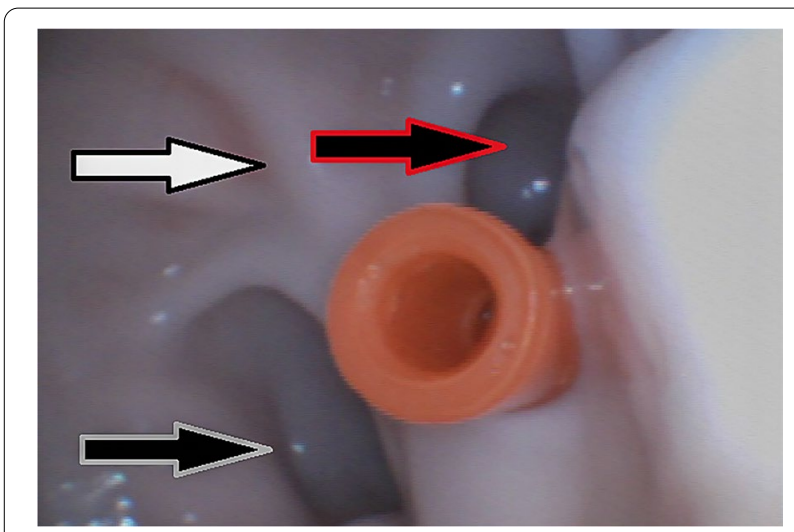

Fig. 4 Internal view of the tube at the end of the procedure, where on the white arrow it is possible to observe the caudal dorsal blind sac, signaled by the yellow arrow, the caudal pillar can be seen, and pointed by the black arrow the caudal ventral blind sac. Three-way stop-cock coupling

\section{Rumenoscopy}

The corpses were positioned in right lateral decubitus. For the procedure, a flexible endoscope $8.9 \mathrm{~mm}$ in diameter and $1100 \mathrm{~mm}$ in length was used (Endovision T $190 \mathrm{k}$, GDI do Brasil, SP, Brazil). The endoscope was introduced through the oral cavity of the fetus, entering the esophagus, where it was necessary to inflate the organ for visualization, using the endoscope's air pump. The endoscope was introduced until the moment when it was possible to visualize the rumen, which also required being inflated to visualize the ruminal structures and perform the rumenostomy technique. Transabdominal illumination was performed to locate the endoscope end and, by palpation of the flank, establish the exact to insert a 18G catheter mandrel (Fig. 1).

\section{Rumenostomy}

Once the site of insertion of the mandrel was established, the catheter mandrel was inserted and the guide probe was passed through it, using $0.60-\mathrm{mm}$ nylon thread, with the length varying according to the size of the fetus (Fig. 1A). The guide was seized by the endoscopic grasping forceps alligator jaws, which was passed through the endoscope's working channel. Then the guide was taken to the mouth of the experimental piece and the outer tip of a size 14 gastric probe was fixed to the guide. The guide was then moved to the inside of the rumen and then to the point of insertion of the guide on the flank. By tractioning the guide, the entrance hole was enlarged with scalpel just enough for the probe to exit (Fig. 2). After that, the probe was sutured using the Chinese knot stitch technique and coupled to a three-way valve to manage content collection and air intake in the rumen (Figs. 3 and 4).

The entire procedure was timed and thedata on the visualization of ruminal structures, decubitus, inflation, illumination, and probe positioning were described, and the average procedure time was obtained.

\section{Supplementary Information}

The online version contains supplementary material available at https://doi. org/10.1186/s12917-022-03143-5.

Additional file 1.

\section{Acknowledgements}

The authors would like to thank the Coordination for the improvement of Higher Education Personnel (CAPES), the National Council for Scientific and Technological Development (CNPq), the Amazon Foundation for Research Support (FAPESPA) and the Pará Federal University (UFPA).

\section{Authors' contributions}

GMAS was responsible for conceptualization, methodology, data curation, validation, investigation, resources, data curation, writing - original draft, writing - review \& editing, visualization, supervision and project administration. LPBB was responsible for data curation, writing - original draft, writing - review \& editing and visualization. LMM was responsible for data curation, writing original draft, writing - review \& editing and visualization. BCG was responsible for data curation, writing - original draft, writing - review \& editing and visualization. RSA was responsible for methodology, data curation, validation, investigation, writing - original draft, writing - review \& editing and visualization. KCR was responsible for data curation, writing - original draft, writing - review \& editing and visualization. HJGwas responsible for methodology, data curation, validation, investigation, writing - original draft, writing - review \& editing and visualization. CESF was responsible for data curation, writing - original draft, writing - review \& editing and visualization. JPMB was responsible for data curation, writing - original draft, writing - review \& editing and visualization. PSR was responsible for data curation, writing - original draft, writing - review \& editing and visualization. FDOM was responsible for data curation, validation, investigation, resources, writing - original draft, writing - review \& editing, visualization and supervision. CSF was responsible for conceptualization, data curation, validation, investigation, writing - original draft, writing - review \& editing and visualization. PPMT was responsible for conceptualization, methodology, data curation, validation, investigation, resources, writing - original draft, writing - review \& editing, visualization, supervision and project administration. All authors read and approved the final manuscript.

\section{Funding}

No funding was obtained for this study.

\section{Availability of data and materials}

All data generated or analysed during this study are included in this published article [and its supplementary information files].

\section{Declarations}

Ethics approval and consent to participate

This study was carried out in accordance with the recommendations of the National Council for Experimentation Control in Brazil (CONCEA). This research was approved by the Animal Ethics and Welfare Committee of the Federal University of Pará (CEUA/UFPA), protocol number 4848261017 (ID 001416).

\section{Consent for publication}

Not applicable.

\section{Competing interests}

The authors declare that they have no competing interests. 


\section{Author details}

${ }^{1}$ Veterinary Hospital, Veterinary Institute, Federal University of Pará (HV/IMV/ UFPA) Castanhal Campus II, Br 316, Km 62, Castanhal, PA 68743-970, Brazil.

${ }^{2}$ University of Rio Verde (UNIRV), Rio Verde, Goiás, Brazil.

Received: 1 October 2021 Accepted: 3 January 2022

Published online: 17 January 2022

\section{References}

1. Babkine M, Desrochers A, Bouré L, Hélie P, et al. Ventral laparoscopic abomasopexy on adult cows. Can Vet J. 2006;47(4):343-8.

2. Barros FFPC, Teixeira PPM, Silva MAM, Coelho CMM, Lopes MCS, Kawanami $A E$, et al. Single-port laparoscopic ovariectomy using a pre-tied loop ligature in Santa Ines ewes. Cienc Rural. 2015;45(11):2033-8.

3. Bleul U, Hollenstein K, Kähn W. Laparoscopic ovariectomy in standing cows. Anim Reprod Sci. 2005;90:193-200.

4. Bouré L. General principles of laparoscopy. Vet Clin Food Anim. 2005;21:227-49.

5. Callan RJ, Applegate TJ. Temporary Rumenostomy for the treatment of forestomach diseases and enteral nutrition. Vet Clin Food Anim. 2017;33(3):525-37.

6. Cheluvappa R, Scowen P, Eri R. Ethics of animal research in human disease remediation, its institutional teaching; and alternatives to animal experimentation. Pharmacol Res Perspect. 2017:5:1-14

7. Chiesa OA, Von Bredow J, Smith M, Thomas M. One-port video-assisted laparoscopic kidney biopsy in standing steers. Res Vet Sci. 2009;87:133-4.

8. Danielsson R, Dicksved J, Sun L, Gonda H, Müller B, Schnürer A, et al. Methane production in dairy cows correlates with rumen methanogenic and bacterial community structure. Front Microbiol. 2017;8(226). https:// doi.org/10.3389/fmicb.2017.00226.

9. Devitt CM, Cox RE, Hailey JJ. Duration, complications, stress, and pain of open ovariohysterectomy versus a simple method of laparoscopicassisted ovariohysterectomy in dogs. J Am Vet Med A. 2005;227(6):921-7.

10. Duarte ALL, Cattelan JW, Bezerra MB, Vicente WRR, Cordeiro MF. Laparoscopic-assisted hepatic biopsy with tru-cut needle in caprines. Arq Bras Med Vet Zootec. 2009;61(1):12-9.

11. Einhorn LM, Taicher BM, Greene NH, Reinstein LJ, Jooste EH, Campbell MJ et al. Percutaneous endoscopic gastrostomy vs surgical gastrostomy in infants with congenital heart disease. Pediatr Anesth. 2018;00:1-6.

12. Elices Mínguez R, Revuelta Rueda L, Martínez-Darve J, Miguélez FS. Surgery technique for ovine ruminal cannulation. Rev Comp Cienc Vet. 2010;4:41-52.

13. Franz $\mathrm{S}$, Baumgartner W. A retrospective study of oesophageal endoscopy in cattle (Bos taurus) and oesophagoscopy for diagnosis of mucosal disease. Vet J. 2002;163:205-10.

14. Franz S, Gentile A, Baumgartner W. Comparison of two ruminoscopy techniques in calves. Vet J. 2006:172(2):308-14.

15. Franz S, Dadak AM, Schoffmann G, Khol JL, Baumgartner W, Dupre G. Laparoscopic-assisted cystotomy: an experimental study in male sheep. Vet Med. 2009;54(8):367-73.

16. Gauderer MWL, Ponsky JL, Izant RJ Jr. Gastrostomy without laparotomy: a percutaneous endoscopic technique. J Pediatr Surg. 1980;15(6):872-5.

17. Griffin MA, Culp WTN, Garcia T, Glaiberman CB, Giuffrida MA, Balsa IM, et al. Percutaneous radiologically guided gastrostomy tubes: Procedural description and biomechanical comparison in a canine model. Vet Surg. 2020:1-9. vsu.13454. https://doi.org/10.1111/vsu.13454

18. Harper L, Herbst K, Kalfa N. Ethical issues in research: human and animal experimentation. J Pediatr Uro. 2018;14(3):286. https://doi.org/10.1016/j. jpurol.2017.10.019.

19. Janowitz H. Laparoskopische Reposition und Fixation des nach links verlagerten abmagen beim Rind. Tierärztl Prax. 1998;26:308-13.

20. Joffe AR, Bara M, Anton N, Nobis N. The ethics of animal research: a survey of the public and scientists in North America. BMC Med Ethics. 2016;17(1). https://doi.org/10.1186/s12910-016-0100-x.

21. Jones K, Case JB, Evans B, Monnet E. Evaluation of the economic and clinical feasibility of introducing rigid endoscopy and laparoscopy to a small animal general practice. J Am Vet Med A. 2017;250(7):795-800.

22. Kaba T, Abera B, Kassa T. Esophageal groove dysfunction: a cause of ruminal bloat in newborn calves. BMC Vet Res. 2018;14:276.
23. Martin C, Morgavi DP, Doreau M. Methane mitigation in ruminants: from microbe to the farm scale. Animal. 2010;4(3):351-65.

24. Matera A. Fístula Experimental do rúmen em bovinos. Braz J Vet Res Anim Sci. 1989;26(2):223-7.

25. McBride BW, Berzins R, Milligan LP, Turner BV. Development of a technique for gastrointestinal endoscopy of domestic ruminants. Can J Anim Sci. 1983;63:349-54.

26. Monteiro FDO, Gurgel HJ, Sousa SS, Barroso JPM, Vasconcelos GPB, Santos $\mathrm{DL}$, et al. Intra-abdominal resection of the umbilical vein and urachus of bovine fetuses using laparoscopy and celiotomy: surgical time and feasibility (cadaveric study). Sci Rep. 2021;11:5328. https://doi.org/10.1038/ s41598-021-84621-y.

27. Muzzi LAL, Muzzi RAL, Gabellinni ELA. Comunicação técnica defistulação e canulação do rúmen em bovinos e ovinos. Ciênc Agrotec Lavras. 2009;33:2059-64

28. Pacheco GFE, Saad FMOB, Trevizan L. Aspectos éticos no uso de animais de produção em experimentação científica. Acta Vet Bras. 2012;6(4):260-6.

29. Prado OPP, Zeoula LM, Moura LPP, Franco SL, Prado IN, Jacobi G. Efeito da adição de própolis e monensina sódica na digestibilidade e características ruminais em bubalinos alimentados com dieta à base de forragem. $R$ Bras Zootec. 2010;39(9):2055-65.

30. Rizzo H, Soares LLS, Oliveira CCM, Cruz JALO, Ono MSB, Souto PC. Indigestão vagal em mini-bovinos no Estado de Pernambuco. Ciênc Vet Tróp. 2015;18(2):121-4.

31. Santos GMA, Barbosa AEC, Borges LPB, Morais HLM, Guilherme BC, Siqueira LS, et al. Minimally invasive video-assisted rumenostomy in sheep. Small Rumin Res. 2018;167:78-81.

32. Spanghero M, Chiaravalli M, Colombini S, Fabro C, Froldi F, Mason F, et al. Rumen inoculum collected from cows at slaughter or from a continuous fermenter and preserved in warm, refrigerated, chilled or freeze-dried environments for in vitro tests. Animals. 2019;815(9):1-14.

33. Stedile R, Beck CAC, Nóbrega FS, Filho APFS, Ferreira MP, Alievi MM, et al. Rumenostomia com colocação de cânula flexível em ovinos. Acta Sci Vet. 2008;36(1):35-8.

34. Teixeira PPM, Padilha LC, Motheo TF, Silva MAM, Oliveira MEF, Silva ASL, et al. Ovariectomy by laparotomy, a video-assisted approach or a complete laparoscopic technique in Santa Ines sheep. Small Rumin Res. 2011;99:199-202

35. Teixeira PPM, Silva MAM, Viana RB. Two-stage Rumenostomy in buffaloes. Acta Sci Vet. 2014;42:1210.

36. Watson RWG, Redmond HP, Mccarthy J, Burke PE, Bouchier-Hayes D. Exposure of the peritoneal cavity to air regulates early inflammatory responses to surgery in a murine model. Br J Sur. 1995;82:1060-5.

37. Zeoula LM, Beleze JRF, Geron LJV, Maeda EM, Prado IN, Paula MC. Digestibilidade parcial e total de rações com a inclusão de ionóforo ou probiótico para bubalinos e bovinos. R Bras Zootec. 2008;37(3):563-71.

38. Zhang S, Hao M, Ma Y. Comparison of laparoscopic and traditional abomasal cannulation in sheep. J Vet Res. 2016;60:113-7.

\section{Publisher's Note}

Springer Nature remains neutral with regard to jurisdictional claims in published maps and institutional affiliations.

Ready to submit your research? Choose BMC and benefit from:

- fast, convenient online submission

- thorough peer review by experienced researchers in your field

- rapid publication on acceptance

- support for research data, including large and complex data types

- gold Open Access which fosters wider collaboration and increased citations

- maximum visibility for your research: over 100M website views per year

At BMC, research is always in progress.

Learn more biomedcentral.com/submissions 